\title{
STARCH DEGRADATION AND NUTRITION VALUE IMPROVEMENT IN CORN GRITS BY SOLID STATE FERMENTATION TECHNIQUE WITH CORIOLUS VERSICOLOR
}

\author{
Mian Huang; Song Zhang*
}

College of Life Science, South China Normal University, Guangzhou, P.R. China.

Submitted: November 29, 2009; Returned to authors for corrections: April 15, 2011; Approved: June 06, 2011.

\begin{abstract}
The study was conducted to evaluate effect of Coriolus versicolor mycelia on degrading starch and improving nutrition value in corn grits through solid state fermentation technique. The results showed that using soybean meal as a nitrogen source, $\alpha$-amylase secreted from C. versicolor expressed $407.25 \mathrm{U} / \mathrm{g}$ of activity, leading to $45.15 \%$ of starch degraded. The activity grew with fermentation time until the $15^{\text {th }}$ day, after that the amylase was deactivated rapidly. An orthogonal experiment designed for the study illustrated that degradation rate of starch in corn grits attained to maximum, $50.51 \%$, when $100 \mathrm{~g}$ of corn grits, added $16 \mathrm{~g}$ of soybean meal, were fermented by C. versicolor for 12 days, in an initial $\mathrm{pH}$ 5.5. After fermenting, compared to the nonfermented control, contents of amino acids, total sugar, crude fat and crude protein were increased by $21.00 \%, 38.45 \%, 55.56 \%, 69.15 \%$ respectively. The significant improvement of nutrition value in corn grits is probably attributed to the intense metabolism of $C$. versicolor.
\end{abstract}

Key words: Coriolus versicolor, corn grits, starch, solid state fermentation, $\alpha$-amylase

\section{INTRODUCTION}

Coriolus versicolor is a distinguished medicinal mushroom, owning functions on anti-age, immunoregulation (13), treating multiple hepatitis (4), inhibiting diverse cancer cells proliferation $(7,8,10)$. It also has a certain efficacy on decreasing toxic actions and side effects from chemotherapeutic drugs, and treating $\operatorname{AIDS}(15,16)$. At present, $C$. versicolor polysaccharide is used widely to cure hepatitis, and glycoprotein from its mycelia has been employed as an anticancer drug in Japan for decades. Besides, cases on turning it into food addictives and health-caring medicine are reported in domestic and abroad. But they are mainly operated by submerged liquid fermentation (SLF). Studying $C$. versicolor by solid state fermentation (SSF) has not been reported.

Compared with SLF, SSF expresses its advantages on simpler culture condition, better product properties, less capital investment, environmental pollution (14). It is commonly employed for production of multiple enzymes from microorganisms $(1,19)$, but seldom for improvement of food nutrition value.

Corn grits, being able to prevent hypertension and heart disease by micronutrients in them, show certain nutritional

*Corresponding Author. Mailing address: College of Life Science, South China Normal University. Guangzhou, P.R. China.; Tel.: 86 020 85216139-8226.; Email: zhangs@scnu.edu.cn 
advantages in cereal. But the high starch content could lead to a low absorption (18). C. versicolor, as a species of rot fungi, has a strong ability to decompose and reuse carbohydrate. Thus, we considered that nutrition of corn grits may be changed by cultivating $C$. versicolor mycelia in corn grits medium.

We describe here a series of experiments on SSF by $C$. versicolor in corn grits medium. We also analyze the activity of $\alpha$-amylase secreted by $C$. versicolor and main nutritional components in the fermented product and the nonfermented control.

\section{MATERIALS AND METHODS}

\section{Fungus}

The strain $\mathrm{Y} 1$ of $C$. versicolor was preserved in Mushroom Culture Collection, Department of Bioengineering, College of Life Science, South China Normal University. It was fostered in a PDA medium with the initial $\mathrm{pH} 6.5$ and the cultivation temperature was in a range between 25 and 28 degrees centigrade.

\section{Solid state fermentation}

The basic medium included $100 \mathrm{~g}$ dry corn grits which were moistened with $40 \mathrm{~mL}$ of $1 \mathrm{mg} / \mathrm{mL} \mathrm{KH}_{2} \mathrm{PO}_{4}$ buffer $(\mathrm{pH}$ 6.5 ). The humidity of the medium was about $40 \%$. Addition of different nitrogen source was different: the dry soybean meal was added $10 \mathrm{~g}$ in $100 \mathrm{~g}$ corn grits, tryptone $2 \mathrm{~g}, \mathrm{NaNO}_{3} 2 \mathrm{~g}$, and $\left(\mathrm{NH}_{4}\right)_{2} \mathrm{SO}_{4} 2 \mathrm{~g}$. The solid medium was dispensed into erlenmeyer flasks (250mL capacity). After sterilization, each flask was inoculated with $10 \mathrm{~mL}$ mycelia pellets liquid, and incubated at 25 degrees centigrade in the dark. The entire content of a flask was harvested after fermented some days, for analyzing $\alpha$-amylase activity and the main nutritional components. Three replicates were prepared for each treatment. The control was non-inoculated.

\section{Enzyme extraction and assay}

Two grams of fermented product from a flask was mixed with deionized water and ground in an ice-cold mortar. After centrifuging the homogenate at 3000r/minute for 10 minutes, the supernatant was assayed for $\alpha$-amylase ( $\alpha$-1,4-glucan-4glucanohy-drolase, EC 3.2.1.1) activity, using soluble starch as the substrate. A mixture of $1 \mathrm{~mL}$ of the supernatant, $1 \mathrm{~mL}$ of citric acid buffer ( $\mathrm{pH} 5.6$ ), and $2 \mathrm{~mL}$ of $10 \mathrm{~g} / \mathrm{L}$ soluble starch was incubated at 40 degrees centigrade for 5 minutes. Then the reducing sugar released was determined by the method described by Chen (2), referring to a standard curve of maltose. One $\alpha$-amylase unit $(\mathrm{U})$ was defined as the amount of enzyme producing $1 \mu \mathrm{mol}$ maltose per minute at 40 degrees centigrade from soluble starch.

\section{Main nutritional components assay}

The samples were dried to constant weight at 75 degrees centigrade before main nutritional components assay. Starch content of the dried samples was determined by titration with potassium ferricyanide (9). The starch degradation rate was calculated according to the formula as follows:

Starch degradation rate $(\%)=($ starch content of control starch content of fermented sample)/starch content of control $\times 100$

Total sugar content was determined by phenol-sulphuric acid method (22), and crude fat content was by soxhlet extraction (9). Crude protein content was calculated from nitrogen content, determined by vario EL element analyzer (produced by Elementar Company, Germany). An amino acid analyzer (Hitachi Model 835-50) was used for amino acid determination.

Duncan's multiple range test (3) was utilized to test significant differences among data of the treatment groups and the control at the $1 \%$ level of confidence.

\section{RESULTS}

\section{Effect of species of nitrogen source}

A suitable nitrogen source was chosen necessarily, because of its effect on $\alpha$-amylase degrading starch (17). 
According to Table 1, $\alpha$-amylase of $C$. versicolor was more active in the media added organic nitrogen sources than control and inorganic ones. Specifically, the activity in the medium added soybean meal was superior to added tryptone. Because of that, the starch degradation rate was achieved $45.15 \%$

Table 1. Effect of species of nitrogen source on activity of $\alpha$-amylase secreted by $C$. versicolor and degradation rate of starch in corn grits degrated by the $\alpha$-amylase

\begin{tabular}{lcc}
\hline Nitrogen Source & $\boldsymbol{\alpha}$-amylase activity $\left(\mathbf{U} / \mathbf{g}^{\mathbf{a}}\right)$ & Degradation rate of starch $(\%)$ \\
\hline Soybean meal & $407.25 \pm 45.74 \mathrm{~A}^{\mathrm{b}}$ & $45.15 \pm 0.08 \mathrm{~A}$ \\
Tryptone & $290.06 \pm 26.41 \mathrm{~B}$ & $44.84 \pm 0.02 \mathrm{~B}$ \\
$\mathrm{NaNO}_{3}$ & $163.10 \pm 11.77 \mathrm{C}$ & $44.71 \pm 0.19 \mathrm{~B}$ \\
$\left(\mathrm{NH}_{4}\right)_{2} \mathrm{SO}_{4}$ & $149.67 \pm 7.62 \mathrm{C}$ & $44.13 \pm 0.06 \mathrm{C}$ \\
Control & $143.56 \pm 13.20 \mathrm{C}$ & $44.76 \pm 0.03 \mathrm{~B}$ \\
\hline
\end{tabular}

${ }^{\mathrm{a}}$ One $\alpha$-amylase unit (U) was defined as the amount of enzyme producing $1 \mu \mathrm{mol}$ maltose per minute at 40 degrees centigrade from soluble starch.

${ }^{\mathrm{b}}$ Data in the same column followed by the same letter were not significantly different at the $p<0.01$ level according to Duncan's multiple range test.

\section{Effect of fermentation time}

The $\alpha$-amylase activity and starch content were determined after fermented 5, 10, 15, 20 and 25 days, respectively. Results (Table 2 ) showed that $\alpha$-amylase activity was maximum at the $10^{\text {th }}$ day, but not significantly different to the $15^{\text {th }}$ day at the $p<0.01$ level. Starch degradation rate rose drastically with fermentation time in the first 15 days. But after that, the amylase deactivated rapidly, and the rate rose gently. It suggested that an efficient fermentation time was between or around 10 and 15 days.

Table 2. Effect of fermentation time on activity of $\alpha$-amylase secreted by $C$. versicolor and degradation rate of starch in corn grits degrated by the $\alpha$-amylase

\begin{tabular}{ccc}
\hline Fermentation time (day) & $\boldsymbol{\alpha}$-amylase activity $(\mathbf{U} / \mathbf{g})$ & Degradation rate of starch (\%) \\
\hline 5 & $339.97 \pm 6.00 \mathrm{BC}$ & $45.32 \pm 0.06 \mathrm{D}$ \\
10 & $427.75 \pm 11.96 \mathrm{~A}$ & $46.18 \pm 0.08 \mathrm{C}$ \\
15 & $413.77 \pm 52.61 \mathrm{AB}$ & $46.91 \pm 0.38 \mathrm{~B}$ \\
20 & $332.99 \pm 43.11 \mathrm{BC}$ & $47.31 \pm 0.10 \mathrm{AB}$ \\
25 & $259.35 \pm 15.41 \mathrm{C}$ & $47.61 \pm 0.38 \mathrm{~A}$ \\
\hline
\end{tabular}

\section{Identification of optimum SSF condition}

An orthogonal experiment with 3 factors and 3 levels $\mathrm{L}_{9}\left(3^{4}\right)$ was designed for studying connection among a number of factors and the influence degree of each factor systematically. According to Table 3 , the theoretical optimum SSF condition was as following: $100 \mathrm{~g}$ corn grits supplemented with $16 \mathrm{~g}$ soybean meal, a fermentation time of 12 days, an initial $\mathrm{pH}$ of 5.5. According to range analysis, acting degree of three elements on $C$. versicolor degrading starch was different: soybean meal content $>$ fermentation time $>$ initial $\mathrm{pH}$. At the $p<0.01$ level, soybean meal content was an extremely remarkable factor; at the $p<0.05$ level, fermentation time was a significant one. Orthogonal experiment No.8 was identical to the theoretical optimum SSF condition, and its degradation rate of starch reached maximum, 50.51\%. 
Table 3. Result of orthogonal experiment to identify optimum SSF condition by $C$. versicolor

\begin{tabular}{ccccc}
\hline Experimental No. Soybean meal (g/100g corn grits) & Fermentation time (day) & Initial pH & Degradation rate of starch (\%) \\
\hline 1 & 4 & 7 & 5.5 & $47.82 \pm 0.10$ \\
2 & 4 & 12 & 6.5 & $48.78 \pm 0.34$ \\
3 & 4 & 17 & 7.5 & $48.32 \pm 0.13$ \\
4 & 10 & 7 & 6.5 & $48.00 \pm 0.18$ \\
5 & 10 & 12 & 7.5 & $49.30 \pm 0.67$ \\
6 & 10 & 17 & 5.5 & $49.35 \pm 0.28$ \\
7 & 16 & 7 & 7.5 & $49.14 \pm 0.14$ \\
8 & 16 & 12 & 5.5 & $50.51 \pm 0.37$ \\
9 & 16 & 17 & 6.5 & $49.81 \pm 0.25$ \\
\hline
\end{tabular}

\section{Effect on contents of amino acids in the protein}

Fermented under the condition of orthogonal experiment No.8, each amino acid in the fermented product had an increase in quantity (Table 4). Specifically, glycine and serine were increased by over $50 \%$. Quantity of total essential amino acids increased from 37.79 to
$46.07 \mathrm{mg} / \mathrm{g}$; total amino acids from 96.79 to $117.12 \mathrm{mg} / \mathrm{g}$. But the ratios of essential amino acids to total amino acids in the product and the control were approximately the same. It indicated that SSF by $C$. versicolor might enhance contents of amino acids on the premise of maintaining the protein composition of corn grits.

Table 4. Amino acids contents of the fermented product and the nonfermented control (mg/g sample)

\begin{tabular}{|c|c|c|c|}
\hline Amino acid & Nonfermented & Fermented & Growth rate of amino acid $\left(\%^{a}\right)$ \\
\hline Asp & 7.55 & 10.00 & 32.45 \\
\hline Thr & 2.91 & 4.28 & 47.08 \\
\hline Ser & 2.94 & 4.69 & 59.52 \\
\hline Glu & 19.64 & 20.99 & 6.87 \\
\hline Pro & 8.94 & 9.93 & 11.07 \\
\hline Gly & 3.23 & 5.37 & 66.25 \\
\hline Ala & 7.29 & 8.99 & 23.32 \\
\hline Cys & 1.25 & 1.40 & 12.00 \\
\hline Val & 5.63 & 7.97 & 41.56 \\
\hline Met & 2.73 & 3.09 & 13.19 \\
\hline Ile & 4.69 & 5.95 & 26.87 \\
\hline Leu & 13.05 & 14.28 & 9.43 \\
\hline Tyr & 1.72 & 2.12 & 23.26 \\
\hline Phe & 5.75 & 7.13 & 24.00 \\
\hline Lys & 3.03 & 3.37 & 11.22 \\
\hline His & 2.33 & 2.62 & 12.45 \\
\hline Arg & 4.11 & 4.94 & 20.19 \\
\hline $\mathrm{EAA}^{\mathrm{b}}$ & 37.79 & 46.07 & 21.91 \\
\hline Total $^{\mathrm{c}}$ & 96.79 & 117.12 & 21.00 \\
\hline $\mathrm{E} / \mathrm{T}^{\mathrm{d}}$ & 0.3904 & 0.3934 & \\
\hline
\end{tabular}

a Growth rate of amino acid $(\%)=($ amino acid content of the fermented product - amino acid content of the nonfermented control $) /$ amino acid content of the nonfermented control $\times 100$

${ }^{\mathrm{b}}$ Quantity of total essential amino acids.

${ }^{c}$ Quantity of total amino acids.

${ }^{\mathrm{d}}$ Ratio of essential amino acids to total amino acids. 


\section{Effect on contents of main nutritional components}

Contents of main nutritional components in the fermented product (fermented according to orthogonal Experiment No.8) and the nonfermented control were compared in Table 5. After fermenting, total sugar, including starch and reducing sugar, rose from 54.1 to $74.9 \mathrm{~g}$ in $100 \mathrm{~g}$ substrate, even starch had been decreased by $50.51 \%$ (Table 3 ). The increase rates of crude fat and crude protein were also noticeable, reaching $55.56 \%$ and $69.15 \%$ respectively.

Table 5. Contents of main nutritional components of the fermented product and the nonfermented control

\begin{tabular}{cccc}
\hline Components & $\begin{array}{c}\text { Nonfermented } \\
(\mathbf{g} / \mathbf{1 0 0 g} \text { substrate) }\end{array}$ & $\begin{array}{c}\text { Fermented } \\
(\mathbf{g} / \mathbf{1 0 0 g} \text { substrate) }\end{array}$ & ${\text { Growth rate }\left(\% \mathbf{~}^{\mathbf{a}}\right)}$ \\
\hline Total sugar & 54.1 & 74.9 & 38.45 \\
Crude fat & 2.7 & 4.2 & 55.56 \\
Crude protein & 9.4 & 15.9 & 69.15 \\
\hline
\end{tabular}

${ }^{a}$ Growth rate $(\%)=($ a certain component content of the fermented product - the component content of the nonfermented control)/ the component content of the nonfermented control $\times 100$

\section{DISCUSSION}

Through SSF with C. versicolor, starch content of corn grits was reduced strikingly. It was probably partly because of using soybean meal as a nitrogen source. Soybean contained a certain deal of calcium ion which could activate and stabilize $\alpha$-amylase $(11,20)$. It resulted in a better starch degradation than others. Besides, content of main nutritional components were increased dramatically. Particularly for the increase of protein content, after fermenting, the protein content exceeded several cereals, such as barley grain $(10.2 \mathrm{~g} / 100 \mathrm{~g}$ substrate), buckwheat flour (11.3), oat flour (13.7), wheat flour (15.7) (20). It could be involved in the metabolism of $C$. versicolor: starch of corn grits was degraded into maltose by catalysis of the $\alpha$-amylase; then other amylases converted maltose into fungi polysaccharides, fat and/or carbon skeleton of amino acids (12). The starch degradation and the nutrition value improvement could lead to a great enhancement of digestibility and absorption rate (18).

Similarly, Hericium erinaceum, Ganaderma lucidum and Morchella esculenta have also been investigated the function on enhancing nutrition value of cornmeal by SSF. Both of them expressed similar results to $C$. versicolor $(5,6,21)$. We consider that here the product by SSF is a nutrient combination of corn grits and $C$. versicolor. Cooperation between SSF and medicinal fungi may turn corn grits and other agricultural products into some kinds of new food owning new healthcaring functions. As human being needs to upgrade nutrition value of food for better survive, it can be foreseen that researchers will increasingly focus on this topic and its further studies. In this case, a further investigation on health-caring functions of the fermented product is needed and its importance can readily been seen.

\section{ACKNOWLEDGEMENTS}

This work was supported by Guangzhou Science and Technology Key Project.

\section{REFERENCES}

1. Alegre, Ana Claudia Paiva (2009). Production of thermostable invertases by Aspergillus caespitosus under submerged or solid state fermentation using agroindustrial residues as carbon source. Braz. J. Microbiol. 40(3), 612-622.

2. Chen, Y.Q. (2002). Experimental Methods and Techniques on Biochemistry. Science Press, Peking.

3. Duncan, D.B. (1955). Multiple range and multiple ' $F$ ' test. Biometrics. 11(1), 1-42.

4. Farghali, H.; Masek, K. (1998). Immunopharmacologic agents in the amelioration of hepatic injuries. Int. J. Immunopharmacol. 20, 125-139.

5. Han, J. (2003). Solid-state fermentation of cornmeal with the 
basidiomycete Hericium Erinaceum for degrading starch and upgrading nutritional value. Int. J. Food Microbiol. 80(1), 61-66.

6. Han, J.R.; An, C.H.; Yuan, J.M. (2005). Solid-state fermentation of cornmeal with the basidiomycete Ganoderma lucidum for degrading starch and upgrading nutritional value. Journal of Applied Microbiology. 99, 910-915.

7. Harhaji, L.; Mijatović, S.; Maksimović-Ivanić, D.; Stojanović, M.; Momčilović, M.; Maksimović, V.; Tufegdžić, S.; Marjanović, Ž.; Mostarica-Stojković, M.; Vučinić, Ž.; Stošić-Grujičić, S. (2008). Antitumor effect of Coriolus versicolor methanol extract against mouse B16 melanoma cells: In vitro and in vivo study. Food Chem. Toxicol. 46(5), 1825-1833.

8. Ho, C.Y.; Kim, C.F.; Leung, K.N.; Fung, K.P.; Tse, T.F.; Chan, H.; Lau, C.B. (2006). Coriolus versicolor (Yunzhi) extract attenuates growth of human leukemia xenografts and induces apoptosis through the mitochondrial pathway. Oncol. Rep. 16(3), 609-616.

9. Huang, W.K. (1989). Examination and Analysis of Food. China Light Industry Press, Peking.

10. Jiménez-Medina, E.; Berruguilla, E.; Romero, I.; Algarra, I.; Collado, A.; Garrido, F.; Garcia-Lora, A. (2008). The immunomodulator PSK induces in vitro cytotoxic activity in tumour cell lines via arrest of cell cycle and induction of apoptosis. BMC Canc. 8(1), 78 .

11. Levitzki, A.; Steer, M.L. (1974). The allosteric activation of mammalian $\alpha$-amylase by chloride. Eur. J. Biochem. 41(1), 171-180.

12. Madigan, M.T.; Martinko, J.M.; Parker, J. (2008). Brock Biology of Microorganisms. Pearson Education, State of New Jersey.

13. Maruyama, S.; Akasaka, T.; Yamada, K.; Tachibana, H. (2009). Proteinbound polysaccharide-K (PSK) directly enhanced IgM production in the human B cell line BALL-1. Biomed. Pharmacother. 63(6), 409-412.

14. Muller dos Santos, M.; Souza da Rosa, A.; Dal'Boit, S.; Mitchell, D.A.; Krieger, N. (2004). Thermal denaturation: is solid-state fermentation really a good technology for the production of enzymes? Bioresource Technol. 93(3), 261-268.

15. Ng, T.B.; Wang, H.X.; Wan, D.C.C. (2006). Polysaccharopeptide from the Turkey Tail Fungus Trametes versicolor (L,: Fr.) Pilát inhibits human immunodeficiency virus type 1 reverse transciptase and protease. Int. J. Med. Mushrooms. 8(1), 39-44.

16. Rotolo, G.. (1999). The effectiveness of Coriolus versicolor in the treatment of secondary phenomena associated with HIV. Presented at 10th International Congress of Mucosal Immunology, Amsterdam.

17. Saswati, S.; Sengupta, S. (1990). Regulation by amino acids of $\alpha$ amylase and endo- $\beta(1 \rightarrow 4)$-glucanase induction in mycelial culture of the mushroom Termitomyces clypeatus. Can. J. Microbiol. 36(9), 617-623.

18. Smolin, L.A.; Grosvenor, M.B. (2007). Nutrition: Science and Applications. John Wiley \& Sons Inc., New York.

19. Swain, M.R.; Kar, S.; Ray, R.C. (2009). Exo-polygalacturonase production by Bacillus subtilis CM5 in solid state fermentation using cassava bagasse. Braz. J. Microbiol. 40(3), 636-648.

20. Yang, Y.X. (2005). China Food Composition 2004. Peking University Medical Press, Peking.

21. Zhang, G.; Zhang, F.; Ru, W.; Han, J. (2010). Solid-state fermentation of cornmeal with the ascomycete Morchella esculenta for degrading starch and upgrading nutritional value. World J. Microbiol. Biotechnol. 26, 1520.

22. Zhang, W.J. (1999). Biochemical Technology of Polysaccharides Compound. Shanghai Science and Technology Press, Shanghai. 